\title{
Testate Succession" in the French and Lithuanian Legal Systems (Terminological Peculiarities)
}

\author{
Irina Gvelesiani \\ Associate Professor of the Faculty of Humanities, \\ Ivane Javakhishvili Tbilisi State University, Tbilisi, Georgia \\ irina.gvelesiani@tsu.ge
}

Doi:10.5901/ajis.2014.v3n3p218

\begin{abstract}
The area of family law has suffered crucial changes throughout the centuries. Nowadays, during the times of globalization, these changes are directed towards the internationalization of legal systems of the world. Juridical differences are becoming irrelevant - socio-cultural, socio-economic and political developments of one country influence other countries. The comparative study of these developments is becoming a foundation for future harmonization of the world law. The given paper presents a precise study of the French (capitalistic) and Lithuanian ("almost" capitalistic) "testate successions". It singles out major terminological units and underlines the most prominent peculiarities of the capitalistic and "almost" capitalistic mechanisms of the modes of inheritance.
\end{abstract}

\section{Introduction}

"Inheritance law is the unity of norms, which regulates the legal destiny of a deceased person's property" (Zoidze B., 2000). "It could appear only after the appearance of the private property" (Javakhishvili l., 1984).

The area of family law has suffered crucial changes throughout the centuries. Nowadays, during the times of globalization, these changes are directed towards the internationalization of legal systems of the world. Juridical differences are becoming irrelevant - socio-cultural, socio-economic and political developments of one country influence other countries. The comparative study of these developments is becoming a foundation for future harmonization of the world law.

The given paper presents a precise study of the French (capitalistic) and Lithuanian ("almost" capitalistic) "testate successions". It singles out major terminological units and underlines the most prominent peculiarities of the capitalistic and "almost" capitalistic mechanisms of the modes of inheritance.

\section{2. "Testate Succession" in the Contemporary Lithuanian law}

After a person's death a universal devolution of the estate takes place - "death of the devisor does not bring his property, property rights and duties to a termination. They devolve to the heirs of the deceased, and, in the instances when there are no successors, or none of the successors accepts succession, the rights of the deceased devolve to the state" (Perkumien, Tamašauskienè, 2013).

The contemporary Lithuanian law differentiates two ways of property transference: "Paveldèjimas pagal testamentą" (a testate succession) and "Paveldejjimas pagal istatymą" (an intestate succession). The succession arises by operation of law ("Paveldejjimas pagal istatyma") in the events, when there is no will/testament or the existed testament has been invalidated. In cases of a valid will, "paveldejjimas pagal testamenta" takes place.

The contemporary Civil Code of the Republic of Lithuania makes distinction between the official ("oficialieji testamentas") and private ("asmeninis testamentas") wills. "Oficialieji testamentas" are usually "made in writing in two copies and attested by the notary public or an official of the Consulate of the Republic of Lithuania in the relevant state" (The Civil Code of the Republic of Lithuania, 2011). In contrast to an official will, "asmeninis testamentas" is written up in hand by the testator indicating the first name and surname of the testator, the date ( $a$ year, a month, a day ) and place where the will was made, expressing the true intent of the testator and signed by him" (The Civil Code of the Republic of Lithuania, 2011).

Any type of a will is usually prepared in a written form by one person (a testator - "testatoriaus"). However, the creation of a testament by two persons (only spouses) is also acceptable. Such a testament is called a "joint will" ("bendrasis sutuoktiniy testamentas") and belongs to the category of "official wills". The Article 5.43 of the Lithuanian 
Civil Code gives the following definition of "bendrasis sutuoktiniu testamentas": "By their joint will, the spouses appoint each other as the successors and after the death of one of the spouses, the whole property of the deceased (including the part of the common property of the spouses therefrom) shall be inherited by the surviving spouse, except the mandatory share of succession" (The Civil Code of the Republic of Lithuania, 2011). "Bendrasis sutuoktiniy testamentas" is usually created and sighed by the spouses in the presence of a notary or any other person attesting the will. Besides mutual devolution of the estate, "the spouses may bequeath their whole property or a part thereof to the society for worthy causes or to charity. Such a direction of the will may be effectuated from the property of one of the spouses after his (her) death or from the common property of the spouses after the death of the surviving spouse" (The Civil Code of the Republic of Lithuania, 2011). Generally, the Lithuanian legal system enables the testator to bequeath his/her estate, its part or a single thing to the society for useful or charitable purposes. A successor of such property may be even a legal person established for the execution of the will of a testator.

The given attitude of the Lithuanian Civil Code directly indicates, that testators are free to bequeath their estate to anyone they wish: "1. Any natural person may bequeath all his property or a part thereof (including ordinary house furnishing and household equipment) to one or several persons irrespective of whether they are his heirs by operation of law, likewise to the state, municipalities or legal persons; 2 . A testator may bequeath all his property or a part thereof to legal persons which will have to be established in executing the will, likewise to natural persons not yet conceived and born ; 3. A testator may by his will disinherit one, several or all of his heirs... " (The Civil Code of the Republic of Lithuania, 2011). Despite a vividly expressed freedom of disposition, the law of the Republic of Lithuania, as an integral part of the world civil law system, limits the testator's rights of devolution of the estate by recognizing the so-called "mandatory share" or "legitim" ("privalomoji dalis"). According to the Article 5.20 of the Civil Code of the Republic of Lithuania of 2011:

1. "The testator's children (the adoptees), spouse, parents (the adoptive parents), who were entitled to maintenance on the day of the testator's death shall inherit irrespective of the content of the will a half of the share that each of them would have been entitled to by operation of law (a mandatory share) unless more is bequeathed by the will;

2. The mandatory share shall be determined taking in regard the value of the inheritable estate, including ordinary house furnishing and household equipment" (The Civil Code of the Republic of Lithuania, 2011).

Therefore, the Lithuanian testate succession comprises three major elements:

- testatoriaus (a testator) - a creator of a will;

- ipédinis (an heir) - a person or a legal entity, which receives property from the estate of a deceased, through a will or the laws of intestacy;

- testamentas (a will) - a document created by the testator.

The property of a deceased person can be considered as the fourth and one of the major elements of the contemporary Lithuanian hereditary relationships. Therefore, according to Article 5.1. of the Lithuanian Civil Code:

- "The following shall be subject to succession: material objects (movable and immovable things) and nonmaterial objects (securities, patents, trade marks, etc.) claims of patrimonial character and property obligations of the bequeather; in cases provided for by laws - intellectual property (authors' property rights to works of literature, science and art, neighbouring property rights and rights to industrial property), as well as other property rights and duties stipulated by laws;

- The following shall not be subject to succession: personal non-property and property rights inseparable from the person of the bequeather (right to honour and dignity, authorship, right to author's name, inviolability of creative work, to the name of performer and inviolability of performance), right to alimony and benefit paid for the maintenance of the bequeather, right to pension, except in cases provided for by laws" (The Civil Code of the Republic of Lithuania, 2011).

\section{3. "Testate Succession" in the Contemporary French law}

According to the commonly excepted legal definition: an "inheritance law - sometimes called wills and probate - is concerned with the distribution of a person's property after his (her) death" (Haigh, 2006). It means, that "the successors occupy the part of the deceased person in property relations. This type of permanent link between generations is a sine qua non (an essential precondition) for public stability and perpetuity of cultural, property and spiritual traditions" (The Commentary of the Civil Code of Georgia, 2000) all over the world.

The contemporary French law differentiates two ways of property transference: a testate succession (succession 
testamentaire) and an intestate succession (succession ab intestate, succession légale, succession légitime). An intestate succession arises by operation of law in the events, when there is no will/testament or the existed testament has been invalidated. In cases of a valid will, "succession testamentaire" takes place.

According to the French Civil Code: "Any person may dispose by will, either under the name of appointment of an heir, or under the name of legacy, or under any other denomination suitable for expressing his wish ... A will may not be made in the same instrument by two or several persons, either for the benefit of a third person, or as a mutual and reciprocal disposition" (Civil Code of France, 2006).

The French legal system presents three major types of a will (testament): an holographic will (testament olographe), an authentic will (testament authentique) and a mystic will (testament mystique).

Testament olographe must be handwritten by the will-maker: "An holographic will is not valid unless it is entirely written, dated and signed by the hand of the testator: it is not subject to any other form" (Civil Code of France, 2006).

The "authentic" will (testament authentique) is made in the presence of two notaries or a notary and two witnesses. The testator dictates the will and the notary writes or types it. Afterwards, it is read and signed in the presence of the notary by the testator and witnesses.

A mystic/secret will (testament mystique) is usually "typed or handwritten by the testator or by someone on his/her behalf. It is then signed by the testator and sealed in an envelope in the presence of a notary and two witnesses. The notary creates an acte de suscription registered on the sealed will or envelope. The content remains secret until it is opened on the death of the testator" (French wills). Article 976 of the Civil Code of France gives more precise description of the preparation of "testament mystique": "Where a testator wishes to make a secret will, the paper which contains the dispositions or the paper used as an envelope, if there is one, shall be closed, stamped and sealed up. The testator shall present it thus closed, stamped and sealed up to the notaire and to two witnesses, or he will have it closed, stamped and sealed up in their presence and he shall declare that the contents of that paper is his will, signed by him, and written by him or by another, while affirming in that latter case, that he has personally verified its contents; he shall indicate, in all cases, the mode of writing used (by hand or mechanical)... instrument shall be signed by the testator as well as by the notaire and the witnesses" (Civil Code of France, 2006).

Despite a vividly expressed freedom of disposition, the French law limits the testator's rights of devolution of the estate by recognizing the so-called "reserved heirs" (héritiers réservataires). It's a well-known fact, that in France a person's estate is divided between the quotité disponible (a disposable portion) and the réserve légale (reserved portion). The former is freely disposable by will, while the latter "must go to the protected heirs, regardless of the wishes of the deceased. "The réserve légale protects the interests of children (réservataires) who survive a parent and the reserved portion must pass equally between them, regardless of the wishes of the deceased or of any will. This réserve légale and the quotité disponible are allocated as follows:

\begin{tabular}{|l|c|c|}
\hline \multicolumn{1}{|c|}{ Réservataire } & Réserve (minimum) & Disposable Portion \\
\hline 1 child & $1 / 2$ & $1 / 2$ \\
\hline 2 children & $2 / 3$ equally between them & $1 / 3$ \\
\hline $3+$ children & $3 / 4$ equally between them & $1 / 4$ \\
\hline
\end{tabular}

... Since January 1, 2007, where there are no children, a surviving spouse is able to take all of the estate, in preference to the deceased's parents. Prior to this change in the law, the parent would have inherited a considerable portion of the estate" (Kinnealy L., 2013).

Therefore, the French "testate succession" comprises the following major elements:

- testateur (a testator) - a creator of a will. In case of a female-creator (testatrix), the French term testatrice is used.

- légataire (an heir) - a person or a legal entity, which receives property from the estate of a deceased, through a will;

- testament (a will) - a document created by the testator.

It's worth mentioning, that the French law recognizes a family agreement (Pacte de Famille), which allows persons to get family members to agree to the organization of their inheritance during their lifetime. All interested parties sign "Pacte de Famille" with notaire (a notary) which binds them to agreements made during the life of the deceased.

\section{Conclusions}

All the above mentioned enables us to conclude, that the process of globalization has embraced the whole world. It 
"unites the world communities" (Makstutis A., Tumalavicius V., 2012), facilitates the emergence of political changes and stipulates the integration of the legal systems of different countries. Certain changes can be seen in the laws of the countries of the former USSR. The given paper has presented a comparative analysis of the French law and the Lithuanian legislation, which was formed on the basis of the legal system of the USSR. The major emphasis has been put on the concept of "testate succession" and terms related to it. The carried out research revealed the following peculiarities:

- The contemporary laws of Lithuania and France make distinction between testate and intestate successions. The legal systems of both countries single out three major elements of testate succession: a testator (the Lithuanian testatoriaus; the French testateur; testatrice), an heir (the Lithuanian ipedinis; the French légataire) and a will (the Lithuanian testamentas; the French testament). It's worth mentioning, that the French language makes distinction between male and female testators (testateur - a testator; testatrice - a testatrix). The same terminological distinction cannot be found in the Lithuanian language;

- The laws of Lithuania and France nominate a "will" as the most commonly used legal instrument by which a testator regulates the rights of others over his/her property after his/her death. The legal systems of both countries differentiate official (notarized) and unofficial types of wills. However, the major difference lies in the fact, that the Civil Code of Lithuania recognizes official, private and joint wills. The French legal system has no joint wills ("bendrasis sutuoktiniu testamentas"), but presents a mystic will (testament mystique), which cannot be found in the Lithuanian law;

- The contemporary Lithuanian and French legal systems single out a concept of a "legitim" (the Lithuanian privalomoji dalis; the French réserve légale). However, the ways of devolution of the "legitim" differ in the Lithuanian and French legislations;

- The French law recognizes a family agreement (Pacte de Famille), which allows persons to get family members to agree to the organization of their inheritance during their lifetime. However, the concept of Pacte de Famille cannot be found in the Lithuanian legal system.

Finally, it's worth mentioning, that the comparative analysis of the Lithuanian and French legal systems revealed their major differences and similarities. Obviously, the existed terminological and conceptual gaps will be filled during the flow of time via the influence of ongoing globalizing processes. The Lithuanian testate succession has already undergone important changes after the completion of the Soviet era. Wills acquired holographic forms and simplified the process of the transference of property. Supposedly, the final establishment of capitalism (in Lithuania) will "increase the homogeneity" of the Lithuanian and French legal systems.

\section{References}

Civil Code of France. Retrieved from http://www.docstoc.com/docs/35310164/civil-code

French Wills. Retrieved from http://france.angloinfo.com/money/pensions-wills/french-wills/

Haigh, R. (2006). Oxford handbook of legal correspondence. Oxford University Press.

Javakhishvili, I. (1984). Works in twelve volumes. Volume VII. Publishing House of Tbilisi University.

Kinnealy L., Pannone LLP Solicitors (2013) France - to die for...? Retrieved from http://consommacteurs.blogs.com/files/french inheritance_laws_tax_2013.pdf

Makstutis A., Tumalavicius V. (2012). Management of legal knowledge theory and practice: Lithuanian experience. The materials of the international scientific conference "Social and economic dimension of European integration: problems, solutions, perspectives", Part II, Daugavpils Universitates Akademiskais Apgads "Saule".

Perkumienè, D., Tamašauskienė, V. (2013). Peculiarities of real property intestate succession in Lithuania. Legal Theory Review. No 1. The Civil Code of the Republic of Lithuania. (2011). Retrieved from http://www.wipo.int/wipolex/en/text.jsp?file_id=202048

The Commentary of the Civil Code of Georgia (2000). Tbilisi: Samartali.

Zoidze, B. (2000). The old Georgian hereditary law. Upleba. 